\title{
Personality Development Variables and Academic Cheating Behaviour among Undergraduate Students of the Faculty of Education, University of Uyo, Uyo
}

\author{
Ime N. George, PhD \\ Department of Educational Foundations, Guidance and Counselling, Faculty of Education, University of \\ Uyo, Uyo, Nigeria \\ E-mail: georgeime62@gmail.com
}

\begin{abstract}
This study was a survey of some selected personality development variables on the academic cheating behaviour of undergraduate students in the Faculty of Education, University of Uyo, Uyo. This study was informed by the observation that various attempts to prevent academic cheating have made limited gains. Three independent personality development variables were identified for the study namely gender roles, peer-group pressure and parental pressure. Three research questions and three null hypotheses were formulated to guide the study. The expost facto survey design was adopted for the study. Instrument for data collection was the Personality Development Variables and Academic Cheating Behaviour Questionnaire (PTVACBQ) developed by the researcher. The questionnaire was validated by three experts from the Faculty of Education, University of Uyo. The Cronbach's Alpha reliability estimate of the instrument was 0.84 . Data was collected from a randomised sample of 300 undergraduate students selected through the simple random sampling method from a population of over 6000 regular undergraduate students in the Faculty of Education. Data analysis was done with the use of descriptive statistical tools such as mean, percentages, and standard deviation to provide answers to the research questions. To test the null hypotheses, independent t-test and analysis of variance was used. All hypotheses were tested at .05 levels of significance. The result of data analyses show that gender roles, peer-group pressure, and parental pressure significantly influenced academic cheating among the students. Based on these findings, it was recommended that psychoacademic interventions should be put in place within and outside the faculty to assist students overcome dishonest tendencies in their academic work.
\end{abstract}

Keywords: Academic cheating; Personality development; Counselling; Adolescence; Education

DOI: $10.7176 /$ RHSS/10-17-06

Publication date:October $31^{\text {st }} 2020$

\section{INTRODUCTION}

Personality may be seen as the dynamic and organized set of characteristics possessed by a person that uniquely influences their environment, cognitions, emotions, motivations, and behaviours in various situations. Personality encompasses the pattern of thoughts, feelings, social adjustments, and behaviours consistently exhibited which also strongly influences the person's expectations, self-perceptions, values, and attitudes and reactions to other people, problems, and stress. In studying personality, various theories and approaches have been advanced to explain the tendencies that underlie differences in behaviour. These approaches include biological, cognitive, learning and trait based theories, as well as psychodynamic, and humanistic approaches. However, it is pertinent to observe that personality development is hugely influenced by external factors to which the individual is exposed. Some of the factors identified in research literature to significantly impact on personality development include gender roles, peer-group pressure and parental pressure. These variables are examined in this study to determine how they influence academic cheating behaviour of students in the Faculty of Education, University of Uyo, Uyo.

Meanwhile, academic cheating behaviour are those conducts on the part of students that undermine examination rules and regulations and serve to give the student undue advantages in educational assessment. This trend is worrisome because it falsifies the ability of the student involved as summarised in performance scores. In spite of this ill and a host of others, it appears that most students in the Faculty of Education consciously thwart any meaningful effort by school authorities to promote academic excellence. In recent times, it has become obvious that the principle to study hard in order to pass examinations has totally been rejected. It is important to correct this trend and boost responsible learning and academic honesty.

The personality factors selected for this study reflect wider social factors that have the potential of predicting 
human behaviour in numerous contexts such as examination malpractices in schools (Anietie, 2011). Denga (2005) identifies social factors that consistently modify human behaviour globally to include peer pressure, religious affiliation, sexual habit, parental rearing style, and economic pressure, among others. For this study, it is believed that such personality influencing factors as peer-group pressure, parental pressure, and gender roles potentially sustain academic dishonesty.

As human personality develops, people begin to identify their biological sexes with social expectations and gender stereotyped behaviour. Locally, it is believed that males are more likely to do certain things than their female counterparts. Academic cheating behaviours are punishable by institutional and legal regulations. Sadly, masculinity with its inherent bravery, risk taking tendencies, athletic capabilities and capacity for swift escape from harm may naturally cause many to assume that male students are more likely to commit examination malpractices than female students. This assumption explains why male-only schools tend to receive stricter security measures during certificate examinations and also tends to explain why most mercenaries of examination malpractices are often found to be males.

Social pressures also play out in the development of personality. These pressure can come from peers or parent, both of whom the individual regards a s significant social figures in their adjustment. For one thing, parents are the education sponsors of most undergraduate students. Naturally, these parents want to see good outcomes from the educational pursuits of their children. Unfortunately, it has been observed that some of these parents would go the extra mile to secure their children's progress in schools by funding examination malpractices, seeing it as an integral part of funding their wards' education. Some parents would even threaten that if the children fail to do all they can to complete their studies in due course, they will withdraw sponsorship. This indirectly compels these students to cheat in their academic work to better their chances of doing well. Peer group pressure also seems to be a strong predictor of academic dishonesty among undergraduate students. Peers could cajole peers to cooperate during examinations and assist each other to gain advantage by sharing ideas or illegal materials during the exams. Other peers could be pressured to fund mercenaries to assist them during examinations. General, it seems that pressure from peers and parents to participate in examination malpractices is a common social problem which merits study.

\section{$1.1 \quad$ Research Objectives}

The main objective of this study was to examine the influence of selected personality development variables on the academic cheating behaviour of undergraduate students in the Faculty of Education, University of Uyo, Uyo. Specifically, the study examined how:

1. Gender roles influence the academic cheating behaviour of undergraduate students in the Faculty of Education, University of Uyo, Uyo.

2. Peer-group pressure influences the academic cheating behaviour of undergraduate students in the Faculty of Education, University of Uyo, Uyo.

3. Parental pressure influences the academic cheating behaviour of undergraduate students in the Faculty of Education, University of Uyo, Uyo.

\subsection{Significance of the Study}

This study will be of immense benefit to researchers, school administrators, especially school counsellors, students, parents, government officials, policy makers, and stakeholders in education. The findings from this study will be a timely addition to existing literature on examination malpractices in the study area. It will also provide reliable guidance for education stakeholders in the areas of further research, policy making, and other appropriate sociological interventions. In addition to the empirical significance of this study, it will also be of significance to the application of learning theories in the school system. It is hoped that the finding would expand current understanding of the dynamics of behaviour theories, especially as it pertains to the sociological functions of the school.

School administrators are hoped to benefit from this study. The findings of this study will provide school administrators, principals and proprietors, with research evidence on the variables that predict examination malpractices. Moreover, the recommendations and suggestions that will be provided in this report would further assist school administrators to know appropriate intervention strategies to forestall examination malpractices in their respective schools.

Students are also hoped to find this study beneficial. The study would assist students to be wary of situations that may make them prone to the menace of examination malpractices and ways to avoid such situations. Moreover, 
the students would further benefit by gaining awareness of the far reaching negative consequences of examination malpractices. The outcome of this study would also assist students to understand the dynamics of peer group pressure and parental influence and how to prevent coming under such negative influence to participate in examination malpractices.

Parents would also find the findings of this study of immense significance. It is hoped that this study would assist parents to be alert to the longer term destructive consequence of examination malpractices on the future socio-economic development of their children. This would dissuade parents who are inclined to pressure their wards to participate in examination malpractices. It would also provide impetus for parents to support the fight against examination malpractices by playing their role in encouraging scholarship instead of funding examination fraud.

The government is also hoped to find the outcome of this study significant. The outcome of this research work would assist the government and her education ministries to identify the variables that increase the likelihood for students to take part in examination malpractices. This study would also enable the government to know how to control these variables through the recommendations that this study will provide, in order to reduce or even prevent students from taking part in examination malpractices.

\subsection{Research Questions}

The following research questions guided the study:

1. How does gender role influence the academic cheating behaviour of undergraduate students in the Faculty of Education, University of Uyo, Uyo?

2. How does peer-group pressure influence the academic cheating behaviour of undergraduate students in the Faculty of Education, University of Uyo, Uyo?

3. How does parental pressure influence the academic cheating behaviour of undergraduate students in the Faculty of Education, University of Uyo, Uyo?

\subsection{Research Hypotheses}

The following hypotheses were tested in the study:

1. Gender role does not significantly influence the academic cheating behaviour of undergraduate students in the Faculty of Education, University of Uyo, Uyo.

2. Peer-group pressure does not significantly influence the academic cheating behaviour of undergraduate students in the Faculty of Education, University of Uyo, Uyo.

3. Parental pressure does not significantly influence the academic cheating behaviour of undergraduate students in the Faculty of Education, University of Uyo, Uyo.

\section{REVIEW OF RELATED LITERATURE}

Bassey, Okure, Otu, and Omang (2009) in their ex-post facto survey examined correlates and factors of examination malpractices in secondary schools in Cross River State, Nigeria. They studied a random sample of one thousand two hundred students. The researchers used standard questionnaires for data collection. They hypothesized that there is no significant influence of location of school and level of examination supervision on students' participation in examination malpractices in their study area. The results they obtained showed that school location and level of examination supervision did significantly influence examination malpractices in the secondary schools they studied. They explained that schools located in the hinterland were more likely to engage in misconduct because accessibility is very difficult and government officials and other examination syndicates could hardly monitor examinations. They further observed that loose supervision enabled students to adopt different methods of carrying extraneous materials into examination halls without the knowledge of those supervising. Modalities and suggestions for curbing examination malpractices in public and private examinations and schools were suggested.

Udoh (2013) studied the types, agents and factors sustaining examination malpractices in Nigeria. The researcher used a random sample of 200 undergraduate students of the University of Uyo, Nigeria who had taken WAEC/NECO Senior School Certificate Examination and the University Matriculation Examination (JAMB) with which they secured admission into the University. The researcher developed a standard questionnaire for data collection. The researcher reported, based on the research data obtained, that 'giraffing' and carrying of prepared materials into the examination hall were the most common forms of examination malpractices, while bribery (ranked 4.5) was the anchor amongst the types of examination malpractices found. The researcher further posited 
that students, peer group and parents were the worst perpetrators of examination malpractices in that decreasing order of culpability. The researcher went further to report that overvaluing of certificates and teachers' ineffectiveness (including poor teaching method and failure to cover subject syllabuses) were the strongest causes of exam misconduct while poor remuneration of teachers was identified as the basic factor sustaining examination malpractices. Based on these findings, Udoh (2013) recommended, among other things, that a more reasonable salary structure for teachers should be provided.

Olowodunoye and Titus (2011) examined in their study the influence of parenting styles, gender and religiosity on the attitude of students towards examination malpractices. The study was a survey of the psychological factor that influence university students' attitude towards examination malpractices. The independent variables were parenting style, gender and religiosity while the dependent variable was attitude towards examination malpractices. Each of the independent variables has sub-levels. Parenting style appears in three (3) levels, gender has two levels (2) and religiosity has two (2) levels. Therefore, the design for the study is $3 \times 2 \times 2$ factorial. One hundred and ninety -eight participants were used which comprises of 100 males and 98 females of AdekunleAjasin University, Akungba- Akoko in Ondo state. Parental care scale developed by Baumrid (1971), Religiosity affiliation scale developed by Omoluabi (1995) and Attitude towards examination cheating scale developed by Alarape and Onakoya (2003) were used to gather data from the students. The results showed that a very high positive significant correlation was found between parenting styles and religiosity $(\mathrm{r}(187=0.308$, $\mathrm{p}<0.01)$. Also between parenting style and examination malpractices, a significant negative relationship was found $(\mathrm{r}(187)=-0.146, \mathrm{p}<.05)$. A significant negative relationship also existed between religiosity and examination malpractices $(\mathrm{r}(187)=-0.028, \mathrm{p}<0.01)$. The ANOVA confirmed the influence of parenting style on the attitude of students toward examination malpractices $(\mathrm{F}(1,186)=2.431, \mathrm{p}<0.05)$. It also confirmed that high religious students did not engage in examination malpractices $\mathrm{F}(1,186)=10.517, \mathrm{p}<0.01)$. But there was no joint significant influence of the three independent variables on the dependent variable $(F(1,186)=0.761, p>0.05)$. The researchers recommended, based on their findings, that among other things, parents should try to inculcate good moral behaviour in their children right from childhood. Let them understand the importance of some values like hard work, integrity, honesty etc. and they themselves should be a good role model to their children. They should be able to stand and condemn any unwanted behaviour spotted in their children.

Udoh (2011) examined remote causes of examination malpractices in the Nigerian education system and attempted to suggest new ways of combating the problem. Three research hypotheses were formulated to guide the study. The researcher employed the multistage stratified sampling technique to select 200 students for the study from 20 secondary schools in Akwa Ibom State. A validated Examination malpractices Questionnaire (EMQUE) was used to collect data for the study. Three research hypotheses were tested statistically using the Chi square statistical technique. The results indicate that poor study habits, paucity of educational facilities, and inability of schools to cover prescribed syllabuses are significant remote causes of examination malpractices in the country. Based on these findings, methods of tackling the menace were proffered and counselling implications suggested. The researcher also maintained that parental pressure presents a formidable force behind the perpetration of examination malpractices. Udoh (2011) argues that many parents would not want their children to repeat any class no matter their level of performance. Thus, they pressure school authorities to give their children automatic promotion even when they fail their examinations. Parents are also in the forefront of hiring mercenaries to write examinations for their wards. They thus collude with principals to issue fake but favourable examination results to their children.

\section{RESEARCH METHODS}

\subsection{Design of the Study}

This study made use of the ex-post facto survey research design. Shaughnessy, Zechmeister and Jeanne (2011) posited that the ex-post facto survey allows a researcher to study already present or currently existent phenomena using a representative sample of a larger population. Hence, this design was considered most suitable for this study. The design allowed the researcher to use a representative sample of students to examine the existent influence of the selected independent variables on the dependent variable. The survey design was also considered most suitable because it was not possible for the researcher to manipulate the independent variables of this study through experiments to see if they could influence the dependent variable.

\subsection{Area of the Study}

The area of study is the Faculty of Education, University of Uyo, Uyo. The Education Faculty is one of the 12 Faculties of the University. It is situated in the town campus of the University along Ikpa Road, Uyo. As at the 
time of this study, the Faculty has nine (9) Departments and over five-thousand undergraduate students in the regular degree programmes. The nine departments are Department of Educational Foundations, Guidance and Counselling; Department of Industrial and Technology Education, Department of Business Education; Department of Agriculture and Home Economics Education; Department of Early Childhood and Special Education; Department of Curriculum Studies, Educational Management and Planning; Department of Science Education; Department of Educational Technology, Library and Information Science; and Department of Physical and Health Education.

\subsection{Population of the Study}

The population for this study comprised all the regular undergraduate students in the Faculty of Education as at the time of this study. The student population is estimated at over 6000 as the $2019 / 2010$ admission was still in progress (Faculty Office, 2020).

\subsection{Sample and Sampling Technique}

A sample size of 300 (about $5 \%$ of the over 6000) students was drawn through the simple random sampling method. The sample were chosen at various lecture halls across the Faculty to ensure representativeness of the population in the sample.

\subsection{Instrumentation}

The research instrument entitled Personality Type Variables and Academic Cheating Behaviour Questionnaire (PTVACBQ) developed by the researcher was used in data collection. The questionnaire had two major sections, A and B. Section A collected demographic information of respondents. Section B contained the scales for assessing other research variables. Each of the scale was graduated on the four points rating scale of Strongly Agree (4 points), Agree (3 points), Disagree (2 points) and Strongly Disagree (1 point).

\subsubsection{Validation of the Instrument}

The validity of the research questionnaire was established using three experts in social studies and measurement and evaluation, from the Faculty of Education, University of Uyo. The validation ensured that the items in the questionnaire were well written to ensure face validity; fully represented the objective of the study, to ensure content validity; and covered all the variables being examined accurately, to ensure construct validity.

\subsubsection{Reliability of the Instrument}

The Cronbach's Alpha method of reliability estimate was used in testing the reliability of the research instrument. In doing this, 20 neutral respondents were made to complete copies of the questionnaire. Their responses were subsequently scored using the weights on the scale and the weighted scores were entered into the reliability analysis. This yielded the Cronbach's Alpha coefficient of 0.84 .

\subsection{Method of Data Collection}

The researcher gathered the research data in person, visiting each lecture venue in the faculty to personally administer the questionnaire. At each of the lecture venues copies of the questionnaire were randomly given to students to complete. They were allowed sufficient time to do so. Moreover, the respondents were provided clarifications where needed in order to ensure correct responses were provided. Completed copies of the questionnaire were retrieved and coded for scoring and subsequent analysis.

\subsection{Method of Data Analysis}

Data generated from the survey questionnaire was analysed to provide answers for the research questions and were also used in testing the null hypotheses. To provide answers to the research questions, descriptive statistical analysis was done to obtain weighted mean scores and standard deviations. The null hypotheses were tested using independent t-test at .05 level of significance and 299 degrees of freedom.

\section{RESULT OF DATA ANALYSES}

4.1 General Description of Data

The research data generated with the questionnaire was collated using the numerical weights of the four-point 
scale. Hence, all the responses were quantified by weights and collated for the dependent and some of the independent variables namely: examination malpractices, socially ascribed gender roles, peer group pressure, and parental influence. The data was analysed using descriptive statistics like simple percentages and mean scores to provide the answers to all the research questions. Afterwards, the data was further analysed using appropriate inferential statistics to test the three null hypotheses. In the analyses, the independent variables (Gender roles, parental pressure, and peer group pressure) were used as grouping variables in the analyses. This allowed the researcher to effectively show how each of the independent variables contributed to academic cheating behaviour of the students.

\subsection{Answers to Research Questions}

Research Question 1: How does gender role influence the academic cheating behaviour of undergraduate students in the Faculty of Education, University of Uyo, Uyo?

Table 1: Gender roles and academic cheating behaviour

\begin{tabular}{llccc}
\hline Dependent Variable & Gender & N & Percentage (\%) & Mean \\
\hline & Male roles & 150 & $50 \%$ & 29.03 \\
Examination malpractices & Female roles & 150 & $50 \%$ & 34.67 \\
& & & & \\
\hline
\end{tabular}

In Table 1, examination malpractices mean scores indicate that being female predicted a greater chance for examination malpractices. The female students had a higher mean of 34.67 whereas the male students had a lower mean of 29.03. This answers the research question on how gender roles contribute to examination malpractices, showing that female students participate in examination malpractices more than their male peers because they are far less scrutinised since society naturally looks more at male criminality and ignores female's potential for crime.

Research Question 2: How does peer-group pressure influence the academic cheating behaviour of undergraduate students in the Faculty of Education, University of Uyo, Uyo?

Table 2: Peer-group pressure and academic cheating behaviour

\begin{tabular}{llccc}
\hline Dependent Variable & Peer Group Pressure & $\mathrm{N}$ & Percentage (\%) & Mean \\
\hline $\begin{array}{l}\text { Examination } \\
\text { malpractices }\end{array}$ & Negative pressure & 117 & $39 \%$ & 34.37 \\
& Positive pressure & 183 & $61 \%$ & 28.11 \\
\hline
\end{tabular}

The descriptive statistics presented in Table 2 shows that students who faced negative peer group pressure scored an average of 34.37 in the examination malpractices instrument while those who experienced positive peer group pressure scored an average of 28.11 on the same instrument. To answer the research question on how peer-pressure contributes to examination malpractices, the data analysed shows that negative peer group pressure contributed to examination malpractices to a greater extent than positive peer group pressure.

Research Question 3: How does parental pressure influence the academic cheating behaviour of undergraduate students in the Faculty of Education, University of Uyo, Uyo?

Table 3: Parental pressure and academic cheating behaviour

\begin{tabular}{lcccc}
\hline Dependent Variable & Parental Pressure & N & Percentage (\%) & Mean \\
\hline $\begin{array}{l}\text { Examination } \\
\text { malpractices }\end{array}$ & Negative pressure & 84 & $28 \%$ & 36.22 \\
& Positive pressure & 216 & $72 \%$ & 27.18
\end{tabular}

Table 3 shows that negative parental pressure contributed to examination malpractices to a greater extent when compared with positive parental pressure. It could be observed that the students who were influenced by their parents to take part in examination malpractices had a mean score of 36.22 on the examination malpractices 
instrument whereas students who were not influenced by parents to participate in examination malpractices scored an average of 27.18 on the examination malpractices instrument.

\subsection{Hypotheses Testing}

Hypothesis 1: Gender role does not significantly influence the academic cheating behaviour of undergraduate students in the Faculty of Education, University of Uyo, Uyo.

Table 4: Independent t-test of gender roles and academic cheating behaviour

\begin{tabular}{|c|c|c|c|c|c|}
\hline Dependent Variable & Gender & $\mathrm{n}$ & $\bar{\chi}$ & SD & $t$-calc. \\
\hline & Male roles & 150 & 29.03 & 6.75 & 3.02 \\
\hline Examination malpractices & Female roles & 150 & 34.67 & 4.34 & \\
\hline
\end{tabular}

The result presented in Table 4 shows that the calculated t-value of 3.02 was greater than the critical value of the t-test of 1.96 at 299 degrees of freedom. Hence, the null hypothesis was rejected. Gender role was therefore found to significantly influence the academic cheating behaviour of undergraduate students in the Faculty of Education, University of Uyo, Uyo. The analysis indicated that female students were more likely to engage in examination malpractices as they recorded a higher mean score than male students.

Hypothesis 2: $\quad$ Peer-group pressure does not significantly influence the academic cheating behaviour of undergraduate students in the Faculty of Education, University of Uyo, Uyo.

Table 5: Independent t-test of peer group pressure and academic cheating behaviour

\begin{tabular}{llcccc}
\hline Dependent Variable & Peer Group Pressure & $\mathrm{n}$ & $\bar{\chi}$ & SD & $t$-calc. \\
\hline & Negative pressure & 117 & 34.37 & 3.21 & 8.16 \\
Examination malpractices & Positive pressure & 183 & 28.11 & 4.81 & \\
& & & & & \\
\hline
\end{tabular}

*Significant at $p \leq .05 ; \mathrm{t}$-critical $=1.96 ; \mathrm{df}=299$

The independent t-test presented in Table 5 show that the calculated value of the t-test (8.16) was greater than critical value of 1.99 at 299 degrees of freedom. Therefore, the null hypothesis which stated that peer group pressure does not significantly contribute to examination malpractices was rejected. This means that negative peer group pressure has a significant influence on the academic cheating behaviour of undergraduate students in the Faculty of Education, University of Uyo, Uyo.

Hypothesis 3: Parental pressure does not significantly influence the academic cheating behaviour of undergraduate students in the Faculty of Education, University of Uyo, Uyo.

Table 6: Independent t-test of parental influence on academic cheating behaviour

\begin{tabular}{llcccc}
\hline Dependent Variable & Parental Influence & $\mathrm{n}$ & $\bar{\chi}$ & $\mathrm{SD}$ & $t$-calc. \\
\hline & Negative pressure & 84 & 36.22 & 4.21 & 9.41 \\
Examination malpractices & Positive pressure & 216 & 27.18 & 5.61 & \\
& & & & & \\
\hline
\end{tabular}

*Significant at $p \leq .05 ; \mathrm{t}$-critical $=1.96 ; \mathrm{df}=299$

Data from Table 6 shows that the calculated value of the independent t-test (9.41) is greater than the critical table value of the t-distribution (1.96). Therefore, the null hypothesis which stated that parental pressure does not significantly contribute to examination malpractices was rejected. This indicates that negative parental pressure 
has a significant influence on the academic cheating behaviour of undergraduate students in the Faculty of Education, University of Uyo, Uyo.

\subsection{Discussion of the Findings}

The findings of this study showed that gender significantly influenced examination malpractices, with being female a stronger predisposition for examination malpractices. This finding is in agreement with the research findings of Udoh and Ekott (2014) substantially agrees with the finding on this study. Udoh and Ekott (2014) reported from their study that students' behaviours are influenced by gender stereotypes. Arguably, there is some sort of difference between disposition and action and this study examined the predictive valence of gender. This therefore is an indication that the prevailing situation is one where female students hide under their feminine façade to perpetrate examination crimes. Understandably, male students know beforehand that they are being watched closely by examination scouts and would naturally prefer not to be involved in examination malpractices. On the other hand, females tend to believe since they are not the prime suspects, they can participate with impunity.

In this study negative peer group pressure was examined and it was found that peer group pressure significantly influenced academic cheating behaviour of undergraduate students in the Faculty of Education, University of Uyo, Uyo. This finding is in agreement with the findings of Dewey (2008) and King et al (2004) who, in their separate studies, found that peers exert a persuasive influence of each other in the peer group to take part in examination malpractices. This study, like the previous ones cited here has provided empirical data to show that peer who are part of a peer group that perpetrate examination malpractices usually come under pressure to do the same. As noted by Udoh and Ekott (2014), even where the peer pressure is negative, it serves the purpose of the group as it fosters behavioural homogeneity which further strengthens the group. Martin et al (2005) also showed that peers come to develop behavioural like-mindedness over time as they interact. Hence the findings of this study that negative peer group pressure has a significant influence on examination malpractices is an indication that when students start developing acquaintance with other students who misconduct during examination, they may come to adopt a similar disposition over time and begin to participate themselves in various shades of examination malpractices.

This study found that parental influence significantly influenced academic cheating behaviour of undergraduate students in the Faculty of Education, University of Uyo, Uyo. It appears that where these students had parental support and approval to cheat for better grades, they plunged headlong into the crime amassing a very high rating on the examination malpractices scale used in this study. Even though this study suggests that very few parents would influence their wards to take part in examination fraud, it highlights the extent to which parental influence can contribute to and even sustain examination fraud. This finding is in agreement with that of Anzene (2014) who found that parents influenced their wards into examination malpractices by consciously relocating these children to schools where examination malpractices would be perpetrated to obtain better grades for their children. This is also similar to the findings of Udoh (2011) who reported that parents pressure school authorities to augment their children's examination scores in order for these not to repeat classes. Udoh (2011) further posited that parents are in the forefront hiring mercenaries to assist their children during certificate examinations in order for these children to obtain better grades. On the whole, the finding of this study, in concert with previous studies, has provided empirical evidence that parental influence significantly contributes to students' involvement in examination malpractices.

\section{CONCLUSION}

Based on the findings from this study, the following conclusions are drawn:

1. Gender roles significantly influenced academic cheating behaviour of undergraduate students in the Faculty of Education, University of Uyo, Uyo. This study shows that female students are more likely to engage in academic dishonesty than male students.

2. Peer group pressure significantly influenced academic cheating behaviour of undergraduate students in the Faculty of Education, University of Uyo, Uyo. This study shows students whose peers participate in examination malpractices are more likely to do so themselves.

3. Parental pressure significantly influenced academic cheating behaviour of undergraduate students in the Faculty of Education, University of Uyo, Uyo. This study has shown that where parents threaten to withdraw sponsorship students resort to unethical means to pass and obtain good grades.

\section{RECOMMENDATIONS}

Based on the findings of this study, it is recommended that examiners and educators should henceforth pay 
adequate attention to female students during examinations as these are more likely to perpetrate examination malpractices. Students should not be left unmonitored just because they are females. Neither should they be allowed to come into examinations without proper search and check as would be done to their male counterparts.

It is also recommended that educational administrators, school counsellors and classroom teachers should seek out peer groups and use them to assist their members to cultivate appropriate examination attitudes and eschew examination malpractices. This can be done through the constitution of appropriate educational clubs in the school. These clubs will bring students together and they could thus be reached through counselling to develop test taking skills, good study habits, effective reading patterns, and appropriate examination techniques.

Finally, this work recommends that parents be educated on the ills of examination malpractices on the students. They should be assisted to know that when they pressure their wards to utilise examination malpractices in obtaining desirable grades, they are preventing their children from developing important life and work skills. Whereas such training would make for future self-reliance and provide capabilities for work or further training, these students would fail to acquire these capabilities if they do not take their schooling seriously and avoid dependence on examination malpractices for better grades.

\section{REFERENCES}

Anietie, B. B. (2011). Female Adolescent Sexual Behaviour and Medical Implication in Jos, Nigeria. Niger Postgraduate Medical Journal, 11(4), 269-280.

Anzene, S. J. (2014).Trends in Examination malpractices in Nigerian Educational System and its Effects on the Socio-Economic and Political Development of Nigeria. Asian Journal of Humanities and Social Sciences, 2(3), 1-8.

Bassey, J. E., Okure, S. J., Otu, B. D. \& Omang, J. D. (2009). Correlates of Examination malpractices in Secondary Schools in Cross River State, Nigeria. Annals of Modern Education, 1(1), 128-133.

Curtis, J. E., Tepperman, L., \& Albanese, P. (2008).Socialization. Sociology: a Canadian perspective (2nd ed.). Don Mills, Ont.: Oxford University Press.

Denga, D. I. (2005). Human Engineering for High Productivity. Makurdi: New Era Publications.

Dewey, P. (2008). Social Influence in Perception. Retrieved on 01/09/2015 from: http://www.museumstuff.com/ learn /topics/Muzafer_Sherif

Gonzales, N. (2010). Family and Peer Influences on Adolescent Behavior and Risk-Taking. Retrieved on 28/11/2010 from http://www.iom.edu/ /media/Files/Activity\%20Files /Children/AdolescenceWS/Commissioned\%20Papers/dodge_gonzales_paper.pdf

Ibia, I. E. (2015).Bodily Kinaesthetic Intelligence and Youth's Predisposition to Criminal Activities in the SouthSouth Geo-Political Zone of Nigeria. American Journal of Psychology and Behavioral Sciences, 2(3), 7176

Macionis, G. \& John, L. (2010). Sociology (7th Canadian Ed.). Toronto, Ontario: Pearson Canada Inc.

Martin, A, Ruchkin, V, Caminis, A, Vermeiren, R, Henrich, C. C, \& Schwab-Stone, M. (2005). Early to Bed: A Study of Adaptation among Sexually Active Urban Adolescent Girls Younger than Age Sixteen. Journal of the American Academy of Child and Adolescent Psychiatry, 44(4), 358-367.

Maslach, C. (2015). Individuation, gender role, and dissent: Personality mediators of situational forces. Journal of Personality and Social Psychology, 53(6), 1088-1093

Okoro, C. C. \& Udoh, N. A. (2014). Academic Achievement Motivation and Attitude of Public secondary School Students towards Examination malpractices in Uyo Metropolis, Akwa Ibom State, Nigeria. Journal of Research \& Method in Education, 4(5:1), 25-31. 
Olowodunoye, S. A. \& Titus, O. A. (2011). Parenting styles, gender, religiosity and examination malpractices. Gender and Behaviour, 9(2), 3941.

Shaughnessy, J.; Zechmeister, E. \&Jeanne, Z. (2011). Research Methods in Psychology (9th ed.). New York, NY: McGraw Hill.

Siegler, R. (2006). How Children Develop, Exploring Child Develop Student Media Tool Kit \& Scientific American Reader to Accompany How Children Develop. New York: Worth Publishers.

Steinberg, L. (2010). Adolescence. New York: McGraw Hill. pp. 1-434.

Tarrant, M. (2002).Adolescent peer groups and social identity. Social Development 11, 110-123.

Udoh, N. A. \& Ekott, I. B. (2014). Sexuality Education and Counselling-Insights from a Survey of Peer Influence on Adolescent University Students' Sexuality. International Journal of Educational Research and Information Science, 1(4), 43-47.

Udoh, N. A. (2011). Remote Causes and Counseling Implications of Examination malpractices in Nigeria. Student Pulse, 3(10), 585.

Udoh, O. A. (2013). Examination malpractices in Nigeria: Rank-ordering the Types, Agents and Sustaining Factors for a Successful Crackdown. Retrieved on 15/11/2015 from: http://www.ajol.info/index.php/ame/article/view/97906

Welsh, D. P, Grello, C. M, \& Harper, M. S. (2003). When Love Hurts: Depression and Adolescent Romantic Relationships. In Adolescent Romantic Relations and Sexual Behaviour: Theory, Research, and Practical Implications. Edited by Florsheim P. Mahwah, NJ: Lawrence Erlbaum Associates. 